\title{
CuO Rapid Synthesis with Different Morphologies by the Microwave Hydrothermal Method
}

\author{
Max Rocha Quirino ${ }^{\text {, Guilherme Leocárdio Lucena }}{ }^{a *}$,Jackson Andson Medeiros ${ }^{a}$,
}

Ieda Maria Garcia dos Santos ${ }^{b}$, Matheus José Cunha de Oliveira ${ }^{c}$

\author{
${ }^{a}$ Laboratório de Química (LABQUIM), Universidade Federal da Paraíba, Campus III, 58200-000, \\ Bananeiras, $P B$, Brasil \\ ${ }^{b}$ Núcleo de Pesquisa e Extensão de Combustiveis e de Materiais (NPE/LACOM), Universidade Federal \\ da Paraíba, Campus I, 58059-900, João Pessoa, PB, Brasil \\ ${ }^{c}$ Eixo de Controle e Processos Industriais, Instituto Federal de Educação, Ciência e Tecnologia do \\ Ceará, Campus Sobral, 62040-730, Sobral, CE, Brasil
}

Received: March 27, 2018; Revised: June 29, 2018; Accepted: August 16, 2018

\begin{abstract}
$\mathrm{CuO}$ structures were synthesized by microwave hydrothermal treatment using two different mineralizing agents $\left(\mathrm{NaOH}\right.$ and $\left.\mathrm{NH}_{4} \mathrm{OH}\right)$ and were evaluated as photocatalysts. The materials were characterized by X-ray diffraction (XRD), scanning electron microscopy (SEM), and Brunauer-EmmettTeller (BET) surface area analysis. The XRD patterns indicated the formation of the monoclinic phase in both samples with 13.78 and $14.23 \mathrm{~nm}$ crystallite size. SEM analysis showed different agglomerates morphologies based on the mineralization agent employed. The $\mathrm{CuO}$ nanostructure synthesized with $\mathrm{NH}_{4} \mathrm{OH}$ presented agglomerated like-plates which results in a spherical shape, whereas the material synthesized with $\mathrm{NaOH}$ presented an agglomerate of larger plates. Both samples showed photocatalytic activity against RNL azo dye. The quasi-spherical shape $\mathrm{CuO}$ material reached $93 \%$ of the discoloration.
\end{abstract}

Keywords: copper oxide, microwave hydrothermal method, photocatalytic.

\section{Introduction}

One copper oxide $(\mathrm{CuO})$ stable form is the tenorite with cation valence $+2^{1}$. This oxide is a p-type multifunctional semiconductor, which has narrow band gap values $(1.2$ - $1.5 \mathrm{eV})^{2-4}$. Its monoclinic structure presents interesting characteristics, such as, thermal superconductivity, thermal stability $^{5}$, photovoltaic properties and antimicrobial activity ${ }^{6}$. This metal oxide has been extensively investigated in recent years due to several applications such as an electric superconductor $^{7}$, battery electrodes for lithium-ion cell ${ }^{8}$, solar sensors ${ }^{9}$, gas sensors ${ }^{10}$, catalysts ${ }^{11}$ and wastewater treatments $^{12}$.

The synthesis of $\mathrm{CuO}$ nanostructures has been obtained by several synthesis methods that apply high temperatures or extensive heat treatments, such as solid state thermal decomposition method $^{13}$, electrochemical ${ }^{14}$, thermal oxidation ${ }^{15}$ and chemical precipitation ${ }^{16}$. The conventional hydrothermal method ${ }^{17}$ applies low temperatures, however, it requires very long synthesis times, and the microwave hydrothermal (MH) method ${ }^{18}$ has been receiving greater attention due its higher heating rate compared to the conventional hydrothermal method. It presents a reaction kinetics increased by one or two orders of magnitude resulting in energy and time savings ${ }^{19-21}$. The reactions are thus completed in minutes or even seconds ${ }^{22}$. Lee et al..$^{23}$ stated that this is viable method to solve economic and environmental problems because it is a closed system that saves energy and time.

*e-mail: guilherme_leo1@yahoo.com.br
Typically oxides synthesized through the MH method present differentiated morphologies such as $\mathrm{CuO}$ in the form of sea urchin ${ }^{18}$; the $\mathrm{BaMoO}_{4}$ in the form of micro octahedra ${ }^{24}$ and the $\mathrm{CaTiO}_{3}$ in the form of microtubes ${ }^{25}$ and multi-linked $\mathrm{ZnO}$ rods ${ }^{26}$. However, these morphologies were achieved due to the use of so-called shape controlling agents such as templates or surfactants like polyethileneglicol MW 200 or special reactants. Therefore, in this communication, we report a synthesis of $\mathrm{CuO}$ with two different morphologies without surfactants or templates, using different hydroxyl source $\left(\mathrm{NH}_{4} \mathrm{OH}\right.$ or $\left.\mathrm{NaOH}\right)$ at $130{ }^{\circ} \mathrm{C}$ for five minutes synthesis.

The degradation of organic pollutants has received special attention in recent years due to the numerous negative effects on the environment and human health. In particular, industrial dyes have been the most common water pollutants ${ }^{27,28}$. These organic dyes have very stable complex structures, which difficult degradation. Among all processes used in these dyes degradation, advanced oxidative processes (AOPs) result in the generation of hydroxyl radicals $(\cdot \mathrm{OH})$, which are used to oxidize organic pollutants to form $\mathrm{CO}_{2}, \mathrm{H}_{2} \mathrm{O}$ or some less toxic inorganic small molecule ${ }^{29,30}$. AOPs have been the most effective technology in removing organic pollutants for water treatment. ${ }^{31,32}$. Currently, semiconductor photocatalysis is a newly developed advanced oxidation process followed by the removal of dye pollutants ${ }^{33}$. Several experiments were carried out to study the photocatalytic activity of some semiconductors, such as $\mathrm{ZnO}, \mathrm{CdS}, \mathrm{SnO}_{2}$ and $\mathrm{ZrO}_{2}$ in the degradation of dyes. Among the range of inorganic semiconductors, $\mathrm{CuO}$ has attracted attention due 
to its easy production, as well as its high chemical and thermal stability, and adjustable electronic properties ${ }^{33,34}$. As a photocatalyst for discoloration of organic dyes, $\mathrm{CuO}$ was evaluated for the degradation of rhodamine B, methyl orange, tartrazine and methylene blue $e^{3,35-36}$. Either way, the $\mathrm{CuO}$ has presented high catalytic activity, being attributed to morphological and superficial aspects.

Thus, in this work, $\mathrm{CuO}$ nanoparticles were obtained by the MH method using two different mineralizing agents aiming to observe their influence on the morphology of the obtained material. It was performed photocatalytic bench tests to analyze the material morphology influence on the degradation of the RNL azo dye.

\section{Experimental}

\subsection{CuO synthesis}

Monoclinic copper (II) oxide was synthesized by the microwave hydrothermal method in a RMW 1 (INOVTEC) reactor.

The applied reagents were $\mathrm{Cu}\left(\mathrm{NO}_{3}\right)_{2} 3 \mathrm{H}_{2} \mathrm{O}(98 \%$, PROQUIMS), $\mathrm{NaOH}\left(98 \%\right.$, ISOFAR) and $\mathrm{NH}_{4} \mathrm{OH}(28 \%$, PROQUIMS).

Initially, in $90 \mathrm{~mL}$ of copper nitrate solution $\left(9 \times 10^{-3}\right.$ mol.L $\left.\mathrm{L}^{-1}\right)$ was added $8 \mathrm{~mL}$ of the solution $\left(5 \mathrm{~mol} . \mathrm{L}^{-1}\right)$ of two different mineralizing agents $\left(\mathrm{NaOH}\right.$ and $\left.\mathrm{NH}_{4} \mathrm{OH}\right)$. Both precursors' solutions with precipitate were individually transferred into a sealed Teflon autoclave and placed in a domestic microwave ( $\mathrm{f}=2450 \mathrm{MHz}$, maximum power $=$ $900 \mathrm{~W})$. The reaction system was treated at $130^{\circ} \mathrm{C}$ with a heating rate of $10^{\circ} \mathrm{C} \cdot \mathrm{min}^{-1}$ for 5 minutes. The autogenous pression in the sealed auclave was stabilized at $1.2 \mathrm{~kg} . \mathrm{cm}^{-2}$ resulting in a black precipitate. Both samples were washed by centrifugation $(400 \mathrm{rpm})$ for ten min three times with distilled water until neutral $\mathrm{pH}$ and then dried at $110{ }^{\circ} \mathrm{C}$ for $12 \mathrm{~h}$. The sample synthesized using the mineralizing agent $\mathrm{NaOH}$ was named $\mathrm{CuNa} 05$ and another one applying $\mathrm{NH}_{4} \mathrm{OH}$ was $\mathrm{CuNH} 05$.

\subsection{Characterization}

Both samples were characterized by X-ray diffraction (XRD), FT-IR spectroscopy (IR), scanning electron microscopy (SEM) and textural analysis.

The XRD patterns were obtained from Shimadzu (XRD 6000 model) operating with $\mathrm{K} \alpha \mathrm{Cu}$ radiation $(\lambda=1.5406)$ in the region of $20-80^{\circ}$ with a step of $0.02^{\circ}$ and a step time of 2 seconds. IR spectra were recorded in the region of 400-800 $\mathrm{cm}^{-1}$ via a Prestige-21 IR Spectrophotometer from Shimadzu. SEM (backscattered-electron) images were obtained on a JEOL-300 microscope. The textural analysis were performed from the adsorption / desorption isotherms of $\mathrm{N}_{2}$ (using the BET equation) on a Bel Japan Belsorp mini II automatic surface area measurement device.

\subsection{Photocatalytic and adsorption tests}

The CuNa05 and CuNH05 samples were used as photocatalysts for the degradation of Remazol Golden Yellow dye (RNL). The molecular structure of the RNL dye is shown in Figure 1.

The photocatalytic tests were performed in a homemade reactor with dimensions of $10 \times 20 \times 100 \mathrm{~cm}$ using UVC lamp ( $\lambda=254 \mathrm{~nm}, 20 \mathrm{~W}$, ILUMISAMPA). The experiments were carried out in triplicate using $10 \mathrm{mg}$ of the photocatalyst and $15 \mathrm{~mL}$ of the dye solution with a concentration of 10 $\mathrm{mg} . \mathrm{L}^{-1}$ at $\mathrm{pH}=6$. Petri dishes containing the dye solution and the photocatalysts were photoirradiated for $1 \mathrm{~h}$. After photocatalysis, the mixtures were centrifuged and filtered.

The percentage of discoloration and degradation of the dye solutions were quantified using a UV-vis spectrophotometer (Model UV-2550, Shimadzu) in absorbance mode by measuring the absorbance of the solution at 411 and 240 $\mathrm{nm}$, respectively ${ }^{38}$. The photocatalytic efficiencies of the photocatalysts were calculated by calibration curves; the initial absorption of the untreated dye solution and the respective concentrations before and after photocatalytic treatment were considered. In addition, tests were performed in the dark, using the same conditions of the photocatalytic tests, to evaluate the discoloration solely due to the adsorption of the dye on the surface of the material.

\section{Results and Discussion}

\subsection{Material characterization}

Figure 2 presents the XRD patterns of the synthesized samples. The diffraction peaks were indexed according to JCPDS $\mathrm{N}^{\circ} 45-0937$, indicating that the monoclinic $\mathrm{CuO}$ phase was obtained for both samples. No commonly impurities' peaks such as $\mathrm{Cu}(\mathrm{OH})_{2}$ or $\mathrm{Cu}_{2} \mathrm{O}$ were detected from this pattern, confirming the pure monoclinic phase for both samples.

Lattice constants were calculated using the method of the least squares, starting from the values arranged in the JCPDS No 45-0937 card.

Using the values of the diffraction angles and the indexing planes, lattice constants, unit cell volume and average crystallite size were calculated. Results are shown in Table 1.

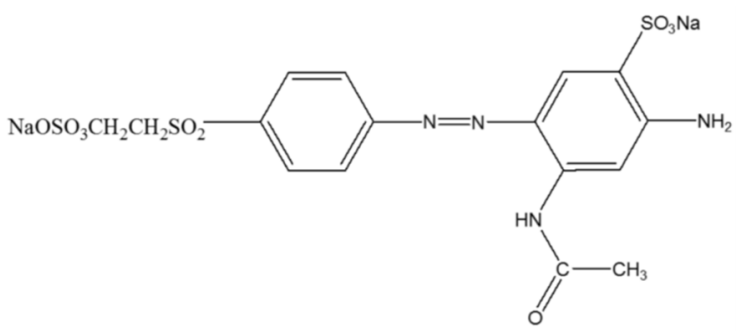

Figure 1. Molecular structure of Remazol Golden Yellow dye (RNL). Adapted from Alvarenga et al. ${ }^{37}$. 


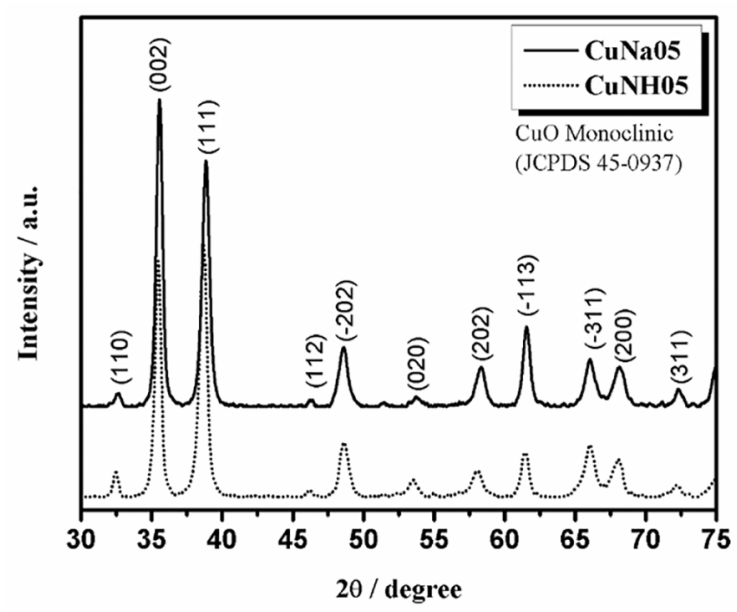

Figure 2 . XRD patterns of $\mathrm{CUNa} 05$ and $\mathrm{CuNH} 05$ samples obtained at $130{ }^{\circ} \mathrm{C}$ for 5 minutes.

According to the results shown in Table 1, the $\mathrm{CuNa05}$ and $\mathrm{CuNH} 05$ samples presented a subtle difference in the network parameters, whereas in comparison with standard (CuO JCPDS $\left.\mathrm{N}^{\mathrm{o}} 45-0937\right)$, the values of a and $\beta$ were reduced and the values of $b$ and $c$ increased. These variations resulted in an increase in unit cell volume of $6.1 \AA^{3}$ for the CuNa05 sample and $7.1 \AA^{3}$ for the CuNH05 sample. This may be occurring due to the experimental conditions (treatment temperature, heating rate and / or processing time) employed in the synthesis which are capable of promoting structural defects formation, residual stresses and/or minor distortions in the lattice constants for this oxide ${ }^{39}$. These small variations may also be due to rapid kinetics in the formation of nanocrystals synthesized through the HMO method $^{39,40}$. Chen et al. ${ }^{41,42}$ observed a similar result when synthesizing mixed aluminum and zinc oxides.

Results indicate the differentiation of the mineralizing agents did not affect the crystallographic parameters relevantly. The average crystallite size (D) of particles was determined by the Scherrer's formula ${ }^{43}$ (equation 1 ).

$$
D=\frac{K \lambda}{\left(L \cos \frac{\chi}{2}\right)}
$$

in which $\lambda$ is the wave-length of the incident $x$-rays, $L$ the linear dimension of particle, $\chi / 2$ the Bragg angle and $K$ a numerical constant for which obtained the value $2(\ln 2 / \pi)^{1 / 2}=0.93$.
For the $\mathrm{CuNa} 05$ sample $\mathrm{D}=13.78 \mathrm{~nm}$ and $14.23 \mathrm{~nm}$ for $\mathrm{CuNH} 05$ sample. Yang et al. ${ }^{44}$ synthesized $\mathrm{CuO}$ by the Microwe hydrothermal method at $120^{\circ} \mathrm{C}$ in 5 min using PEG 400 as template resulting in samples with different morphologies, i.e. quasi-spherical nanoplates, willow-leaf-like and rod like. The D parameter ranging from 11.8 to $15 \mathrm{~nm}$. This slightly variation is also observable in this work.

Low temperatures and short times of synthesis are favorable conditions for the non-growth of particles. Luo et al. ${ }^{40}$ reported that in the synthesis of nest like $\mathrm{BaMoO}_{4}$ nanoparticles; particles grow to a certain extent and then there is re-dissolution in the hydrothermal treatment. This may also be related to the small size of particles in syntheses through the hydrothermal microwave assisted method.

Figure 3 shows the IR spectra for both $\mathrm{CuNa05}$ and CuNH05 samples.

The vibrational modes located at $506 \mathrm{~cm}^{-1}, 570 \mathrm{~cm}^{-1}$ and $603 \mathrm{~cm}^{-1}$ are characteristic of $\mathrm{CuO}$ monoclinic $\mathrm{c}^{45-47}$. The high frequency mode at $603 \mathrm{~cm}^{-1}$ and $570 \mathrm{~cm}^{-1}$ refers to the $\mathrm{Cu}-\mathrm{O}$ stretch around the direction [-110] while the mode at 506 $\mathrm{cm}^{-1}$ is associated to vibration along the direction $[101]^{48}$.

Scanning electron microscopy was used to observe the influence of mineralizing agents on the morphology of materials. SEM images of $\mathrm{CuNH} 05$ and $\mathrm{CuNa} 05$ samples are presented in Figures 4 and 5.

SEM images for both samples present plate-like particles morphology, but the difference between the two samples is in the agglomeration. $\mathrm{CuNH05}$ sample the agglomerates present

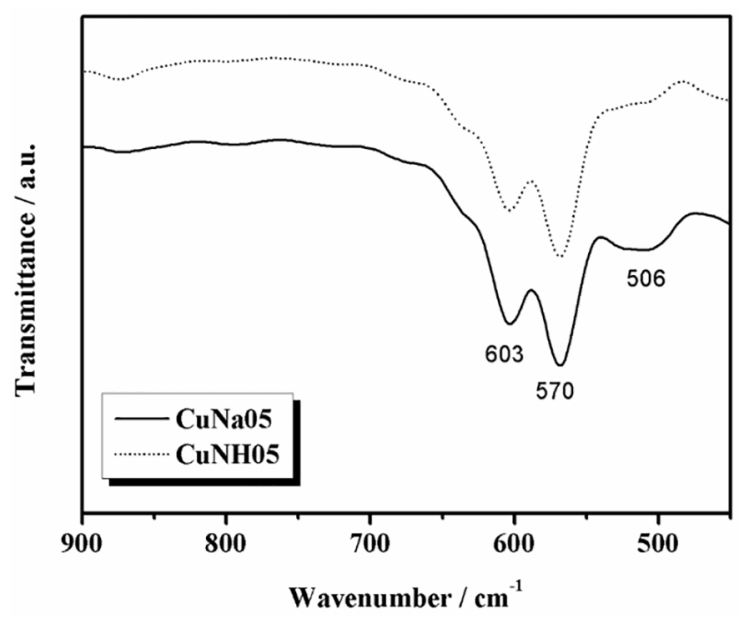

Figure 3. IR spectra of the $\mathrm{CuNa} 05$ and $\mathrm{CuNH} 05$ samples obtained at $130{ }^{\circ} \mathrm{C}$ for 5 minutes.

Table 1. Lattice parameters, unit cell volume (V) and crystallite size (D) of both CuNa05 and CuNH05 samples.

\begin{tabular}{|c|c|c|c|c|c|c|}
\hline \multirow{2}{*}{ Samples } & \multicolumn{4}{|c|}{ Lattice parameters $(\AA)$} & \multirow{2}{*}{$\mathrm{V}\left(\AA^{3}\right)$} & \multirow{2}{*}{$\mathrm{D}(\mathrm{nm})$} \\
\hline & a & $\mathrm{b}$ & $\mathrm{c}$ & $\beta$ & & \\
\hline $\mathrm{CuO}$ (Standard)* & 4.69 & 3.43 & 5.13 & 99.93 & 81.2 & - \\
\hline $\mathrm{CuNa} 05$ & 4.30 & 3.74 & 5.46 & 96.33 & 87.3 & 13.78 \\
\hline CuNH05 & 4.31 & 3.76 & 5.48 & 96.17 & 88.3 & 14.23 \\
\hline
\end{tabular}

*JCPDS card n ${ }^{\circ}$ 45-0937. 


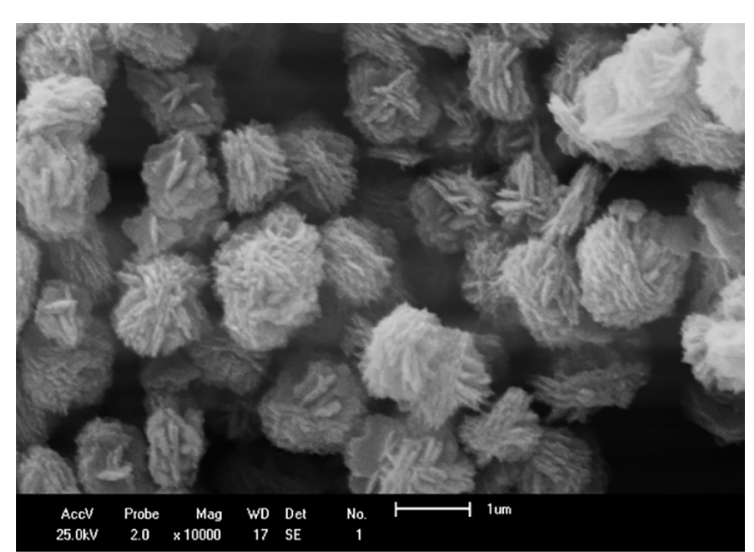

Figure 4. Image obtained by SEM for CuNH05 sample ZONH5 10.000 times.

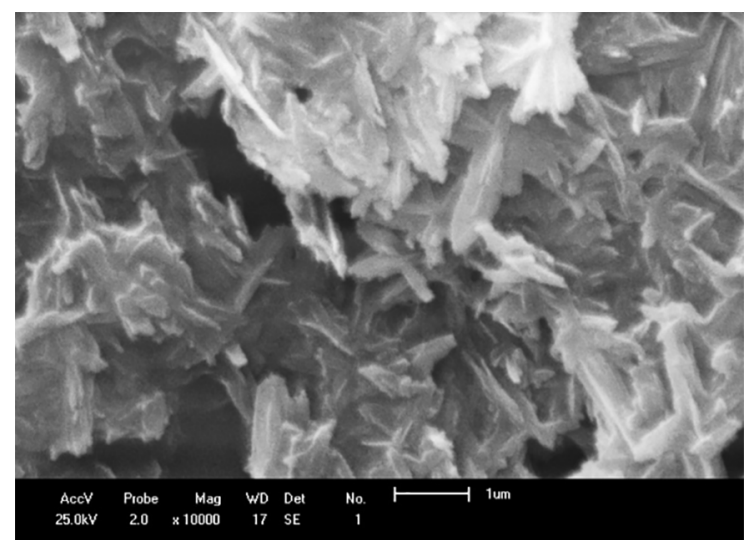

Figure 5. Image obtained by $\mathrm{SEM}$ for $\mathrm{CuNa} 05$ sample ZONH5 10.000 times.

quasi spherical form. It is possible to notice that the material has some smaller quasi-spherical agglomerates and others larger than a micrometer resulting in a small particle size. For the $\mathrm{CuNa} 05$ sample the small plates above large plates resulting in the interconnected channels. With these results it is evident that the agglomeration's morphologies of the copper oxide synthesized was differentiated as a function of the mineralizing agent used.

Keyson et al. ${ }^{18}$ synthesized through the HM method nanostructures similar to sea urchins. In this study the authors synthesized this material with a precursor solution containing polyethylene glycol $400+\mathrm{CuCO}_{3} \cdot \mathrm{Cu}(\mathrm{OH})_{2}+\mathrm{NH}_{4} \mathrm{OH}$ at $120^{\circ} \mathrm{C} / 1 \mathrm{~h}$. They reported that polyethylene glycol $\left(\mathrm{MM}=400 \mathrm{~g} \cdot \mathrm{mol}^{-1}\right)$ played a fundamental role in obtaining the oxide with this differentiated morphology. Through the same method, Maul et al. ${ }^{49}$ evaluated the influence using or not $\mathrm{NaOH}$ and $\mathrm{NH}_{4} \mathrm{OH}$ as mineralizer agents on the $\mathrm{CuO}$ morphology. Using $\mathrm{NaOH}$ in the precursor solution many small particles and plates were observed. While $\mathrm{NH}_{4} \mathrm{OH}$ promoted flower like morphology formed by plates. Without alkali agents small agglomerated particles forming spherical morphologies was observed. These results were similar to those presented in this work, although using time of synthesis twelve times shorter. In another work, Yang et al. ${ }^{50}$ obtained nanoplates and dendrites of $\mathrm{CuO}$. The precursor solution used consisted of copper nitride, PEG 400, $\mathrm{NaOH}$ and urea at a temperature of 120 ${ }^{\circ} \mathrm{C}$ for five minutes. Shi et al. ${ }^{51}$ synthesized $\mathrm{CuO}$ nanorods from a precursor solution of $\mathrm{CuSO} 4.5 \mathrm{H}_{2} \mathrm{O}+\mathrm{PEG} 400+$ polyethylene glycol (4:2) $+10 \mathrm{~g}$ of Urea at $120^{\circ} \mathrm{C} / 5 \mathrm{~min}$.

It was observed that to obtain structures in the micro or nano scales with differentiated morphologies many authors use to attribute to the role of templates, drivers and/or use of surfactants or same precursor solutions containing chitosan, $\mathrm{PEG}, \mathrm{Cu}_{2} \mathrm{Cl}(\mathrm{OH})_{3}+\mathrm{K}_{2} \mathrm{CO}_{3}+\mathrm{CuCl}_{2}$, copper glycinatemonohydrate ${ }^{51-55}$. However in this paper it was possible to obtain differentiated morphology, mainly using the $\mathrm{NH}_{4} \mathrm{OH}$ mineralizer, without special reagents and templates.

Thus it is observed that this method uses low temperature and short time to obtain the $\mathrm{CuO}$ and with possibility of morphology control being influenced mainly to the type of precursor used for the material synthesis.

In this paper, copper oxide II was synthesized through the microwave hydrothermal method in two different ways, resulting two samples with different morphologies distinguishing only two hydroxyl source mineralizing agents: $\mathrm{NaOH}$ and $\mathrm{NH}_{4} \mathrm{OH}$. These precursor solutions had $\mathrm{pH}=13$ and 10 , respectively. As no template or driver was used it is suggested that the $\mathrm{pH}$ difference as a function of the two distinct bases applied is the main factor responsible for the influence on the final morphology of the two copper oxide samples obtained. The reactions are presented in equations 2 to 8 .

$$
\mathrm{Cu}\left(\mathrm{NO}_{3}\right)_{2} \cdot 3 \mathrm{H}_{2} \mathrm{O}_{(a q)} \longrightarrow \mathrm{Cu}(\mathrm{OH})_{2(s)} \downarrow+2 \mathrm{NaNO}_{3(a q)}
$$

$$
\begin{aligned}
& \mathrm{Cu}(\mathrm{OH})_{2(\text { orthothombic })}+2 \mathrm{OH}_{(\text {aq })}^{-} \longrightarrow \\
& \mathrm{Cu}(\mathrm{OH})_{4(s)(\text { Tetrahydroxucupratye II Anion })}^{2-}
\end{aligned}
$$

$\mathrm{Cu}(\mathrm{OH})_{4(s)}^{2-} \underset{130^{\circ} \mathrm{C} / 5 \min }{\longrightarrow} \mathrm{Cu} O_{(s)}$ agglomerated sheets ${ }^{51}$

$$
\begin{aligned}
& \mathrm{Cu}\left(\mathrm{NO}_{3}\right)_{2} \cdot 3 \mathrm{H}_{2} \mathrm{O}_{(a q)}+4 \mathrm{NH}_{3(a q)} \longrightarrow\left[\mathrm{Cu}\left(\mathrm{NH}_{3}\right)_{4}\right]_{(a q)}^{2-} \\
& {\left[\mathrm{Cu}\left(\mathrm{NH}_{3}\right)_{4}\right]_{(a q)}^{2-}+4 \mathrm{OH}_{(a q)}^{-} \longrightarrow \mathrm{Cu}(\mathrm{OH})_{4(a q)}^{2^{-}}+4 \mathrm{NH}_{3(a q)}} \\
& \mathrm{Cu}(\mathrm{OH})_{4(a q)}^{2-} \longrightarrow \mathrm{Cu}(\mathrm{OH})_{2(a q)}+2 \mathrm{OH}_{(a q)}^{-}
\end{aligned}
$$

$$
\mathrm{Cu}(\mathrm{OH})_{2(a q)} \underset{130^{\circ} \mathrm{C} / 5 \mathrm{~min}}{\mathrm{~m}} \mathrm{H}_{2} \mathrm{O}+\mathrm{CuO} \mathrm{O}_{(s)}
$$

sheets agglomerated form quasi-spherical mosphologiy ${ }^{56}$. 
Different mineralizing agents, due to the basic strength of alkalis, lead to different $\mathrm{pH}$. As result the synthesized materials presented different morphologies. High concentrations of copper cations and hydroxyde anions produces copper complex ions, such as $\left[\mathrm{Cu}(\mathrm{OH})_{4}\right]^{2-}$ or $\left[\mathrm{Cu}\left(\mathrm{NH}_{3}\right)_{4}\right]^{2+}$ which are converted to $\mathrm{CuO}^{56}$, in this case by $\mathrm{HM}$. So, the two forms of $\mathrm{CuO}$ materials can be synthesized by using different precursors solutions ions.

Nikan et al..$^{57}$ synthesized nano-belt like morphology by the microwave-assisted wet chemical synthesis at $\mathrm{pH}=10$ from cupper acetate, $100 \mu \mathrm{L}$ of $\mathrm{NaOH}\left(0.1 \mathrm{~mol} . \mathrm{L}^{-1}\right)$ and benzyl alcohol for 1 minute synthesis. $\mathrm{Low} \mathrm{pH}$ lead to $\mathrm{Cu}_{2} \mathrm{O}$ cubes morphology.

Other materials like $\mathrm{ZnO}$ varies its the morphology according to solution $\mathrm{pH}$ values. Ram et al..$^{58}$ synthesized $\mathrm{ZnO}$ by the microwave hydrotermal method $\left(100^{\circ} \mathrm{C} / 2 \mathrm{~min}\right)$ at different $\mathrm{pH}$ values; 8.5 and 10 using ammonia solution $\left(\mathrm{NH}_{4} \mathrm{OH}\right)$ as mineralizer agent and $\mathrm{pH} 10$ and 13.5 using $\mathrm{NaOH}$, without using growth agents or templates. The morphology of the materials varies with $\mathrm{pH}$ increase, starting from nanoflakes, than tapered hexagonal rods, and hexagonal nanorods. This last presenting different size distributions. Also to reinforce the influence of $\mathrm{pH}$ on the syntheses of oxides. Wu et al. ${ }^{59}$ obtained the $\mathrm{ZnO}$ oxide by the $\mathrm{HC}$ at $200^{\circ} \mathrm{C} / 15 \mathrm{~h}$ increasing the $\mathrm{pH}$ value, at $\mathrm{pH}=8.92$ rods structure; 11.78 nanorods; 12.81 sea urchin like and 12.89 flower like morphology. The excess of $[(\mathrm{OH}-)]$ favors nucleation.

Figure 6 presents the $\mathrm{N}_{2}$ adsorption and desorption isotherms of the $\mathrm{CuNa05}$ and $\mathrm{CuNH} 05$ samples.

The plot of adsorbed volume of $\mathrm{N}_{2(\mathrm{~g})}$ against relative pressure $\left(\mathrm{P} / \mathrm{P}_{0}\right)$ for both samples exhibited Type III isotherm (IUPAC) as show in Fig. $6 a$ and $6 b^{60}$. The two samples showed same hysteresis behavior, ie, narrow hysteresis loop. In set Fig. 5(a) and (b) shows pore size distribution. The sample $\mathrm{CuNa} 05$, agglomerated sheets, exhibited larger pore distribution (max. $34.43 \mathrm{~nm}$ ) than $\mathrm{CuNH05}$ which

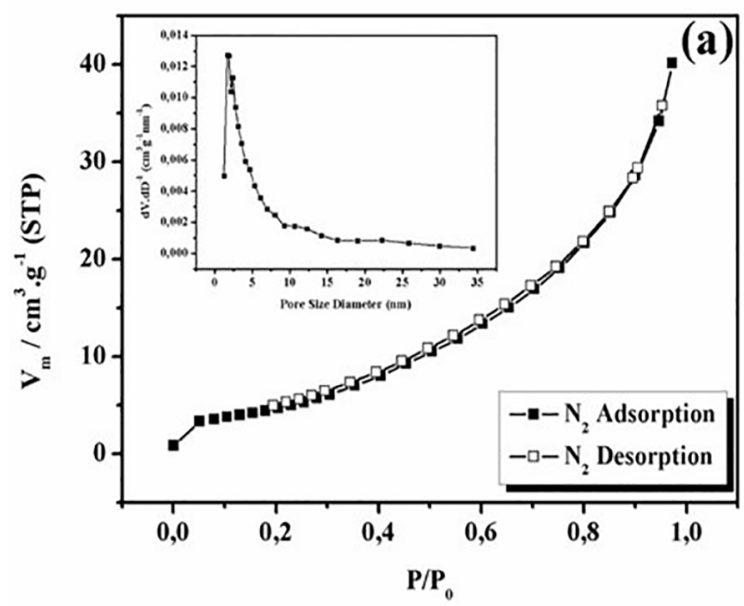

exhibited morphology in form agglomerated sheets resulting quasi-spherical morphology with max pore size $19.04 \mathrm{~nm}$.

Both materials are nanoporous, the relatively low pore diameter in both samples may be attributed to the closely packing of the small particles (sub-units) resulting their final micro-structure. Bhuvaneshwari et al. $2016^{61}$ synthesized via hydrothermally, ie, without microwaves $\mathrm{CuO}$ snowflake, flower, hollowsphere and urchin morphologies. All samples also exhibited Type III isotherm.

From these results, surface area $\left(\mathrm{S}_{\mathrm{BET}}\right)$, pore volume $(\mathrm{Pv})$ and average pore size (Tp) were estimated and the values are presented in Table 2.

According to Table 2, CuNa05 presented twice the surface area $\left(\mathrm{S}_{\mathrm{BET}}\right)$ than $\mathrm{CuNH05}$ sample. Yang et al. ${ }^{52}$ synthesized the $\mathrm{CuO}$ with different morphologies like tadpole-shaped, spindly, leaf/sphere-like, and fusiform $\mathrm{CuO}$ nanoparticles. The specific surface ranging from 18 to $71 \mathrm{~m}^{2} \cdot \mathrm{g}^{-1}$. The $\mathrm{CuNa} 05$ specific surface area is inside this interval and $\mathrm{CuNH} 05$ is out of low limit $\left(11.758 \mathrm{~m}^{2} \cdot \mathrm{g}^{-1}\right)$.

Average pore volume $(\mathrm{Pv})$ of the sample alkalinized with $\mathrm{NaOH}$ was higher than the sample basified with $\mathrm{NH}_{4} \mathrm{OH}$. The average pore size (Ps) was practically uninfluenced by the mineralizing agent. This pore size non-variation possibly is associated with the use of inorganic bases $(\mathrm{NaOH}$ and $\mathrm{NH}_{4} \mathrm{OH}$ ) as a mineralizing agent because they are similar chemical substances (bases). According to the literature, variations in pore size were observed in materials synthesized by hydrothermal and hydrothermal microwave methods that used templates such as PEG $400^{62}$ or organic substances, such as hexane ${ }^{63}$, decane ${ }^{64}$, as pore expansion agents.

Table 2. Textural characteristics of $\mathrm{CuNa} 05$ and $\mathrm{CuNH} 05$ samples.

\begin{tabular}{lccc}
\hline Sample & $\mathrm{S}_{\mathrm{BET}}\left(\mathrm{m}^{2} \cdot \mathrm{g}^{-1}\right)$ & $\mathrm{Pv}\left(\mathrm{cm}^{3} \cdot \mathrm{g}^{-1}\right)$ & $\operatorname{Ps}(\mathrm{nm})$ \\
\hline $\mathrm{CuNa} 05$ & 23.486 & 5.396 & 10.561 \\
$\mathrm{CuNH05}$ & 11.758 & 2.701 & 9.7188 \\
\hline
\end{tabular}

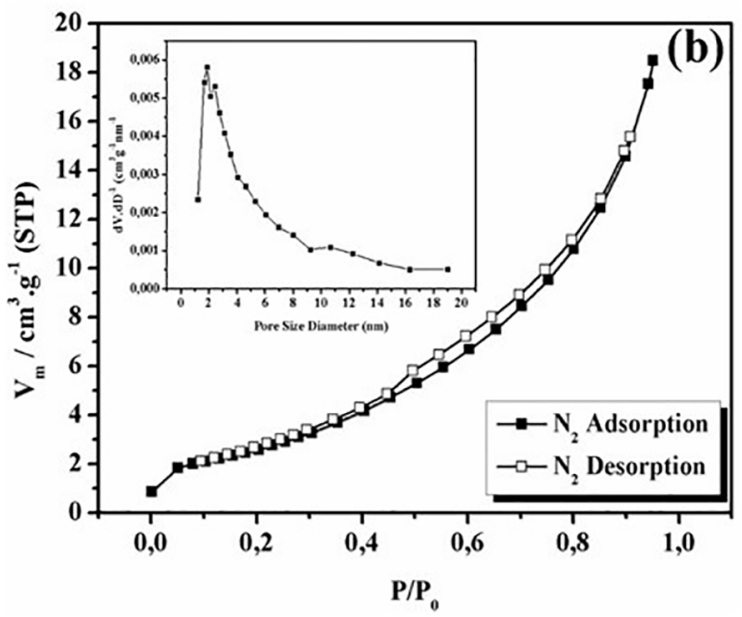

Figure 6. $\mathrm{N}_{2}$ adsorption / desorption isotherms of $\mathrm{CuNa05}$ (a) and $\mathrm{CuNH} 05$ (b). 


\subsection{Photocatalytic efficiency}

The UV-Vis spectra and the percentage discoloration of the RNL dye after the adsorption and photocatalysis processes are shown in Figure 7(a) and (b), respectively.

The quantification of RNL dye degradation is performed by monitoring the absorbance at $240 \mathrm{~nm}$ and $411 \mathrm{~nm}$. The first mode refers to the transitions of the aromatic groups of the UV-Vis spectrum, while the latter is associated with the azo bond $(-\mathrm{N}=\mathrm{N}-)$. Thus, the decrease in the intensity of the band at $411 \mathrm{~nm}$ implies the breakdown of the azo bond or reduction of the dye concentration in solution ${ }^{65}$.

The UV-vis spectra of the RNL dye after the tests with the $\mathrm{CuNa05}$ and $\mathrm{CuNH05}$ samples in the absence of light (Fig. 7a) showed a decrease in signal intensity at $240 \mathrm{~nm}$ and $411 \mathrm{~nm}$, keeping the same profile of the spectrum of pure dye, the discoloration occurred due to adsorption of the dye molecules on the surface of the $\mathrm{CuO}$ particles. It was observed that the percentage of discoloration of azo dye RNL due to adsorption, practically did not change, maintaining the values of $43 \%$ and $45 \%$, for $\mathrm{CuNa} 05$ and CuNH05, respectively. On the other hand, the UV-vis spectra of the RNL dye after the tests performed in the presence of radiation (Fig. $7 b$ ) showed that there was photodegradation and that the discoloration reached $85 \%$ for $\mathrm{CuNa05}$ and 93\% for CuNH05.

When evaluating the photocatalytic efficiency of the $\mathrm{CuO}$ synthesized in this work, it is noticed that the $\mathrm{CuNH} 05$ sample showed an increase of $11 \%$ in the RNL discoloration in relation to the $\mathrm{CuNa} 05$ sample. According to literature ${ }^{3,34,36}$, the change in morphology and surface properties, including higher specific surface area, may be the cause of the enhanced activity. But in this case the shape of particles also influences the photodegradation. Although the $\mathrm{CuNa05}$ sample had a larger surface area than the CuNH05 sample, 23.486 and $11.758 \mathrm{~m}^{2} . \mathrm{g}^{-1}$ respectively, but the photodegradation of the latter sample was slightly higher, demonstrating that the morphology of the particular agglomerates is more influential than the surface area of the catalyst.

\section{Conclusion}

The copper oxide $(\mathrm{CuO})$ was synthesized by microwave hydrothermal method under mild conditions of low temperature and short time synthesis. A significant change in the structures of the $\mathrm{CuO}$ was observed for different precursors without surfactants or templates, varying only alkaline mineralizes $\mathrm{NaOH}$ or $\mathrm{NH}_{4} \mathrm{OH}$ in addition to $\mathrm{Cu}\left(\mathrm{NO}_{3}\right)_{2} \cdot 3 \mathrm{H}_{2} \mathrm{O}$ solutions, separately. The morphologies are affected by the mineralizing agent, the sample, alkalinized with $\mathrm{NH}_{4} \mathrm{OH}$, is in the form of agglomerated plate-like, which results in a quasi-spherical shape. $\mathrm{CuNa} 05$ sample, alkalinized with $\mathrm{NaOH}$, which presents in the form of smaller plates-like on much larger plates. The heterogeneous photocatalysis of these samples was more influenced by the morphology of copper oxide than the surface area, since the alkalinized sample with $\mathrm{NH}_{4} \mathrm{OH}$, quasi-spherical agglomerates and lower surface area, presented greater degradation of the RNL azo dye. This material is an candidate to be used in photocatalysis applications.
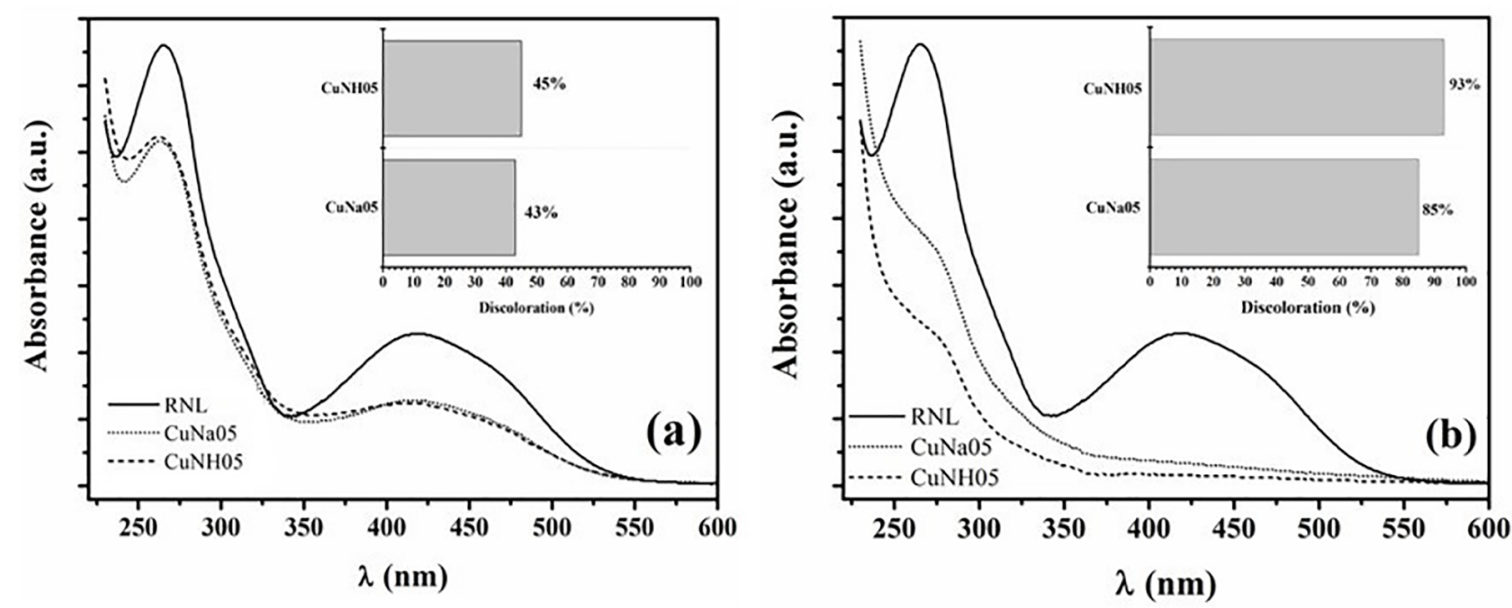

Figure 7. UV-vis spectra of RNL azo-dye, after adsorption (a) and after photocatalytic. test (b), in the presence of $\mathrm{CuNa} 05 \mathrm{and} \mathrm{CuNH} 05$ (inset: percentage of discoloration). 


\section{References}

1. Richthofen AV, Domnick R, Cremer R. Preparation of cuprite $\left(\mathrm{Cu}_{2} \mathrm{O}\right)$, paramelaconite $\left(\mathrm{Cu}_{3}{ }^{2+} \mathrm{Cu}_{2}{ }^{1+} \mathrm{O}_{4}\right)$ and tenorite $(\mathrm{CuO})$ with magnetron sputtering ion plating: characterization by EPMA, XRD, HEED and SEM. Fresenius' Journal of Analytical Chemistry. 1997;358(1-2):312-315.

2. Dong C, Xiao X, Chen G, Guan H, Wang Y. Morphology control of porous $\mathrm{CuO}$ by surfactant using combustion method. Applied Surface Science. 2015;349:844-848.

3. Mageshwari K, Sathyamoorthy R, Park J. Photocatalytic activity of hierarchical $\mathrm{CuO}$ microspheres synthesized by facile reflux condensation method. Powder Technology. $2015 ; 278: 150-156$

4. Zhang Q, Zhang K, Xu D, Yang G, Huang H, Nie F, et al. $\mathrm{CuO}$ nanostructures: Synthesis, characterization, growth mechanisms, fundamental properties, and applications. Progress in Materials Science. 2014;60:208-337.

5. Zhang L, Feng Q, Nie A, Liu J, Wang H, Fang Y. In Situ Study of Thermal Stability of Copper Oxide Nanowires at Anaerobic Environment. Journal of Nanomaterials. 2014;2014:670849.

6. Tran TH, Nguyen VT. Copper Oxide Nanomaterials Prepared by Solution Methods, Some Properties, and Potential Applications: A Brief Review. International Scholarly Research Notices. 2014;2014:856592.

7. MacDonald AH. Copper oxides get charged up. Nature. 2001;414:409-410.

8. Wang $\mathrm{C}, \mathrm{Xu} \mathrm{J}, \mathrm{Ma} \mathrm{R}$, Yuen MF. Facile synthesis of $\mathrm{CuO}$ nanoneedle electrodes for high-performance lithium-ion batteries. Materials Chemistry and Physics. 2014;148(12):411-415.

9. Xia Y, Pu X, Liu J, Liang J, Liu P, Li X, et al. CuO nanoleaves enhance the c-Si solar cell efficiency. Journal of Materials Chemistry A. 2014;2(19):6796-6800.

10. Kim JH, Katoch A, Choi SW, Kim SS. Growth and sensing properties of networked $\mathrm{p}-\mathrm{CuO}$ nanowires. Sensors and Actuators B: Chemical. 2015;212:190-195.

11. Sonia S, Poongodi S, Kumar PS, Mangalaraj D, Ponpandian N, Viswanathan C. Hydrothermal synthesis of highly stable $\mathrm{CuO}$ nanostructures for efficient photocatalytic degradation of organic dyes. Materials Science in Semiconductor Processing. 2015;30:585-591.

12. Reddy KJ, McDonald KJ, King H. A novel arsenic removal process for water using cupric oxide nanoparticles. Journal of Colloid and Interface Science. 2013;397:96-102.

13. Shahsavani E, Feizi N, Khalaji AD. Copper Oxide Nanoparticles Prepared by Solid State Thermal Decomposition: Synthesis and Characterization. Journal of Ultrafine Grained and Nanostructured Materials. 2016;49(1):48-50.
14. Yuan GQ, Jiang HF, Lin C, Liao SJ. Shape- and size-controlled electrochemical synthesis of cupric oxide nanocrystals. Journal of Crystal Growth. 2007;303(2):400-406.

15. Filipic G, Cvelbar U. Copper oxide nanowires: a review of growth. Nanotechnology. 2012;23(19):194001.

16. Zhu J, Bi H, Wang Y, Wang X, Yang X, Lu L. CuO nanocrystals with controllable shapes grown from solution without any surfactants. Materials Chemistry and Physics. 2008;109(1):3438.

17. Chakraborty S, Das A, Sood AK. Mixing of Mode Symmetries in Top Gated Bilayer and Multilayer Graphene Field Effect Devices. AIP Conference Proceedings. 2011;1349(1):11-14.

18. Keyson D, Volanti DP, Cavalcante LS, Simões AZ, Varela JA, Longo E. CuO urchin-nanostructures synthesized from a domestic hydrothermal microwave method. Materials Research Bulletin. 2008;43(3):771-775.

19. Komarneni S, D'Arrigo MC, Leonelli C, Pellacani GC, Katsuki H. Microwave-Hydrothermal Synthesis of Nanophase Ferrites. Journal of American Ceramic Society. 1998;81(11):3041-3043.

20. Komarneni S, Rajha RK, Katsuki H. Microwave-hydrothermal processing of titanium dioxide. Materials Chemistry and Physics. 1999;61(1):50-54.

21. Komarneni S, Katsuki H. Nanophase materials by a novel microwave-hydrothermal process. Pure and Applied Chemistry. 2002;74(9):1537-1543.

22. Roberts BA, Strauss CR. Toward Rapid, "Green", Predictable Microwave-Assisted Synthesis. Accounts of Chemical Research. 2005;38(8):653-661.

23. Lee JH, Kumagai N, Watanabe T, Yoshimura M. Direct fabrication of oxide films by a microwave-hydrothermal method at low temperature. Solid State Ionics. 2002;151(14):41-45.

24. Cavalcante LS, Sczancoski JC, Tranquilin RL, Varela JA, Longo E, Orlandi MO. Growth mechanism of octahedron-like $\mathrm{BaMoO}_{4}$ microcrystals processed in microwave-hydrothermal: Experimental observations and computational modeling. Particuology. 2009;7(5):353-362.

25. Moreira ML, Paris EC, do Nascimento GS, Longo VM, Sambrano JR, Mastelaro VR, et al. Structural and optical properties of $\mathrm{CaTiO}_{3}$ perovskite-based materials obtained by microwave-assisted hydrothermal synthesis: An experimental and theoretical insight. Acta Materialia. 2009;57(17):51745185 .

26. Kathalingam A, Chae YS, Rhee JK. Synthesis of multilinked $\mathrm{ZnO}$ rods by microwave heating. Crystal Research \& Technology. 2011;46(5):517-522.

27. Banazadeh A, Salimi H, Khaleghi M, Shafiei-Haghighi S. Highly efficient degradation of hazardous dyes in aqueous phase by supported palladium nanocatalyst-A green approach. Journal of Environmental Chemical Engineering. 2016;4(2):2178-2186. 
28. Horáková M, Klementová Š, Kř́ǐz P, Balakrishna SK, Špatenka $\mathrm{P}$, Golovko $\mathrm{O}$, et al. The synergistic effect of advanced oxidation processes to eliminate resistant chemical compounds. Surface and Coatings Technology. 2014;241:154-158.

29. Yang Z, Yang Y, Zhu X, Chen G, Zhang W. An Outward Coating Route to $\mathrm{CuO} / \mathrm{MnO}_{2}$ Nanorod Array Films and Their Efficient Catalytic Oxidation of Acid Fuchsin Dye. Industrial \& Engineering Chemistry Research. 2014;53(23):9608-9615.

30. Cheng M, Zeng G, Huang D, Lai C, Xu P, Zhang C, et al. Hydroxyl radicals based advanced oxidation processes (AOPs) for remediation of soils contaminated with organic compounds: A review. Chemical Engineering Journal. 2016;284:582-598.

31. Wang JL, Xu LJ. Advanced Oxidation Processes for Wastewater Treatment: Formation of Hydroxyl Radical and Application. Critical Reviews in Environmental Science and Technology. 2012;42(3):251-325.

32. Li H, Liao J, Zeng $\mathrm{T}$. A facile synthesis of $\mathrm{CuO}$ nanowires and nanorods, and their catalytic activity in the oxidative degradation of Rhodamine B with hydrogen peroxide. Catalysis Communications. 2014;46:169-173.

33. Rao MP, Wu JJ, Asiri AM, Anandan S. Photocatalytic degradation of tartrazine dye using $\mathrm{CuO}$ straw-sheaf-like nanostructures. Water Science and Technology. 2017;75(5-6):1421-1430.

34. Sadollahkhani A, Ibupoto ZH, Elhag S, Nur O, Willander M. Photocatalytic properties of different morphologies of $\mathrm{CuO}$ for the degradation of Congo red organic dye. Ceramics International. 2014;40(7 Pt B):11311-11317.

35. Jiang D, Xue J, Wu L, Zhou W, Zhang Y, Li X. Photocatalytic performance enhancement of $\mathrm{CuO} / \mathrm{Cu}_{2} \mathrm{O}$ heterostructures for photodegradation of organic dyes: Effects of $\mathrm{CuO}$ morphology. Applied Catalysis B: Environmental. 2017;211:199-204.

36. Deka P, Hazarika A, Deka RC, Bharali P. Influence of $\mathrm{CuO}$ morphology on the enhanced catalytic degradation of methylene blue and methyl orange. RSC Advances. 2016;6(97):9529295305 .

37. Alvarenga JM, Fideles RA, Silva MV, Murari GF, Taylor JG, Lemos LR, et al. Partition study of textile dye Remazol Yellow Gold RNL in aqueous two-phase systems. Fluid Phase Equilibria. 2015;391:1-8.

38. Muruganandham M, Swaminathan M. Photocatalytic decolourisation and degradation of Reactive Orange 4 by $\mathrm{TiO}_{2}$-UV process. Dyes and Pigments. 2006;68(2-3):133-142.

39. Rao KJ, Vaidhyanathan B, Ganguli M, Ramakrishnan PA. Synthesis of Inorganic Solids Using Microwaves. Chemistry of Materials. 1999;11(4):882-895.

40. Luo Z, Li H, Shu H, Wang K, Xia J, Yan Y. Synthesis of BaMoO Nestlike Nanostructures Under A New Growth Mechanism. Crystal Growth \& Design. 2008;8(7):2275-2281.

41. Chen Z, Shi E, Li W, Zheng Y, Wu N, Zhong W. Particle Size Comparison of Hydrothermally Synthesized Cobalt and Zinc Aluminate Spinels. Journal of the American Ceramic Society. 2002;85(12):2949-2955.

42. Chen Z, Shi E, Zheng Y, Li W, Wu N, Zhong W. Synthesis of mono-dispersed $\mathrm{ZnAl}_{2} \mathrm{O}_{4}$ powders under hydrothermal conditions. Materials Letters. 2002;56(4):601-605.
43. Patterson AL. The Scherrer Formula for X-ray Particle Size Determination. Physical Review. 1939;56(10):978-982.

44. Yang C, Xiao F, Wang J, Su X. Synthesis and microwave modification of $\mathrm{CuO}$ nanoparticles: crystallinity and morphological variations, catalysis, and gas sensing. Journal of Colloid and Interface Science. 2014;435:34-42.

45. Wang $\mathrm{H}, \mathrm{Xu}$ JZ, Zhu JJ, Chen HY. Preparation of $\mathrm{CuO}$ nanoparticles by microwave irradiation. Journal of Crystal Growth. 2002;244(1):88-94.

46. Zhang L, Lu W, Feng Y, Ni J, Lü Y, Shang X. Facile Synthesis of Leaf-like $\mathrm{Cu}(\mathrm{OH})_{2}$ and its Conversion into $\mathrm{CuO}$ with Nanopores. Acta Physico-Chimica Sinica. 2008;24(12):2257-2262.

47. Sathyamoorthy R, Mageshwari K. Synthesis of hierarchical $\mathrm{CuO}$ microspheres: Photocatalytic and antibacterial activities. Physica E: Low-dimensional Systems and Nanostructures. 2013;47:157-161.

48. Zou GF, Li H, Zhang DW, Xiong K, Dong C, Qian YT. WellAligned Arrays of CuO Nanoplatelets. The Journal of Physical Chemistry B. 2006;110(4):1632-1637.

49. Maul J, Brito AS, de Oliveira ALM, Lima SJG, Maurera MAMA, Keyson D, et al. Influence of the synthesis media in the properties of $\mathrm{CuO}$ obtained by microwave-assisted hydrothermal method. Journal of Thermal Analysis and Calorimetry. 2011;106(2):519523.

50. Yang C, Wang J, Xiao F, Su X. Microwave hydrothermal disassembly for evolution from $\mathrm{CuO}$ dendrites to nanosheets and their applications in catalysis and photo-catalysis. Powder Technology. 2014;264:36-42.

51. Shi L, Yang C, Su X, Wang J, Xiao F, Fan J, et al. Microwavehydrothermal synthesis of $\mathrm{CuO}$ nanorods and their catalytic applications in sodium humate synthesis and $\mathrm{RhB}$ degradation. Ceramics International. 2014;40(3):5103-5106.

52. Yang C, Su X, Wang J, Cao X, Wang SJ, Zhang L. Facile microwave-assisted hydrothermal synthesis of varied-shaped $\mathrm{CuO}$ nanoparticles and their gas sensing properties. Sensors and Actuators B: Chemical. 2013;185:159-165.

53. Raghavendra GM, Jung J, Kim D, Seo J. Chitosan-mediated synthesis of flowery-CuO, and its antibacterial and catalytic properties. Carbohydrate Polymers. 2017;172:78-84.

54. Xie H, Zhu L, Zheng W, Zhang J, Gao F, Wang Y. Microwaveassisted template-free synthesis of butterfly-like $\mathrm{CuO}$ through $\mathrm{Cu}_{2} \mathrm{Cl}(\mathrm{OH})_{3}$ precursor and the electrochemical sensing property. Solid State Sciences. 2016;61:146-154.

55. Huang J, Fu G, Shi C, Wang X, Zhai M, Gu C. Novel porous $\mathrm{CuO}$ microrods: synthesis, characterization, and their photocatalysis property. Journal of Physics and Chemistry of Solids. 2014;75(9):1011-1016.

56. Bozkurt G, Bayrakçeken A, Özer AK. Synthesis and characterization of CuO at nanoscale. Applied Surface Science. 2014;318:244250 .

57. Nikan AV, Arulkashmir A, Krishnamoorthy K, Kulkarni AA, Prasad BLV. pH-Dependent Single-Step Rapid Synthesis of $\mathrm{CuO}$ and $\mathrm{Cu}_{2} \mathrm{O}$ Nanoparticles from the same Precursor. Crystal \& Growth Design. 2014;14(9):4329-4334. 
58. Ram SDG, Kulandainathan MA, Ravi G. On the study of $\mathrm{pH}$ effects in the microwave enhanced rapid synthesis of nano- $\mathrm{ZnO}$. Applied Physics A. 2010;99(1):197-203.

59. Wu WY, Kung WY, Ting JM. Effect of $\mathrm{pH}$ Values on the Morphology of Zinc Oxide Nanostructures and their Photoluminescence Spectra. Journal of American Ceramic Society. 2011;94(3):699-703.

60. Sing KSW, Everett DH, Haul RAW, Moscou L, Pierotti RA, Rouquerol J, et al. Reporting physisorption data for gas/solid systems with special reference to the determination of surface area and porosity. Pure and Applied Chemistry. 1985;57(4):603619.

61. Bhuvaneshwari S, Gopalakrishnan N. Hydrothermally synthesized copper oxide $(\mathrm{CuO})$ superstructures for ammonia sensing. Journal of Colloid and Interface Science. 2016;480:76-84.
62. Quirino MR, Oliveira MJ, Keyson D, Lucena GL, Oliveira JBL, Gama L. Synthesis of zinc oxide by microwave hydrothermal method for application to transesterification of soybean oil (biodiesel). Materials Chemistry and Physics. 2017;185:24-30.

63. Johansson EM, Córdoba JM, Odén M. The effects on pore size and particle morphology of heptane additions to the synthesis of mesoporous silica SBA-15. Microporous and Mesoporous Materials. 2010;133(1-3):66-74.

64. Zhang H, Sun J, Ma D, Weinberg G, Su DS, Bao X. Engineered Complex Emulsion System: Toward Modulating the Pore Length and Morphological Architecture of Mesoporous Silicas. Journal of Physical Chemistry B. 2006;110(51):25908-25915.

65. Stylidi M, Kondarides DI, Verykios XE. Visible light-induced photocatalytic degradation of Acid Orange 7 in aqueous $\mathrm{TiO}_{2}$ suspensions. Applied Catalysis B: Environmental. 2004;47(3):189201. 